\title{
Penggunaan Tindak Tutur Direktif Mahasiswa Multikultural dalam Konteks Kesantunan
}

\author{
The Use of Directive Speech Act by Multicultural Students in the Context of Politeness
}

\author{
Munawwir Hadiwijaya ${ }^{1, *}$, Maya Rizki Amalyasari ${ }^{2}$, dan Yahmun ${ }^{3}$ \\ ${ }^{1,2,3}$ IKIP Budi Utomo, Malang \\ ${ }^{1, *}$ Corresponding email: mr.awinwijaya@gmail.com \\ ${ }^{2}$ Email: mayariskiamalyasari@budiutomomalang.ac.id \\ ${ }^{3}$ Email: yahmun@budiutomomalang.ac.id
}

\begin{abstract}
This study aims to reveal the use of directive speech acts of multicultural students studying in Malang City in the context of politeness. Qualitative descriptive is the method used in this study. Five tribes are the subject of this research, namely Java, Sumba, Flores, Dayak, and Madura. Data were collected using questionnaires, interviews, and observations. The data obtained were analyzed based on how they used directive demand speech act in different situations in the realm of family, friendship, and school and how they minimized the FTA that might occur when facing different speech partners. The results of this study indicate that from the four aspects that become the parameters of this study, multicultural students in using directive speech acts have the following pattern. In the aspect of direct/indirect speech acts, in three different domains, all multicultural students use direct speech acts and the honorific aspect. The use of hedge aspects is more widely used in the campus domain. Meanwhile, in the aspect of speech level, only Javanese and Madurese students use it.

Keywords: directive speech acts, politeness, multicultural students
\end{abstract}

\begin{abstract}
Abstrak: Penelitian ini bertujuan untuk mengungkap penggunaan tindak tutur direktif mahasiswa multikultural yang belajar di Kota Malang dalam konteks kesantunan. Deskriptif kualitatif adalah metode yang digunakan dalam penelitian ini. Terdapat lima suku yang menjadi subjek dari penelitian ini, yaitu Jawa, Sumba, Flores, Dayak, dan Madura. Data dikumpulkan dengan menggunakan kuesioner, wawancara, dan observasi. Data yang diperoleh dianalisis berdasarkan bagaimana mereka menggunakan ujaran direktif permintaan dalam situasi yang berbeda baik dalam ranah keluarga, pertemanan, maupun ranah sekolah dan bagaimana mereka meminimalisir FTA yang mungkin terjadi ketika menghadapi mitra tutur yang berbeda. Hasil penelitian ini menunjukkan dari empat aspek yang menjadi parameter penelitian ini, mahasiswa multikultural dalam menggunakan tindak tutur direktif memiliki pola sebagai berikut. Dalam aspek tindak tutur langsung/tidak langsung, di tiga ranah berbeda, semua mahasiswa multikultural menggunakan tindak tutur langsung, begitu pula dalam aspek honorifik. Penggunaan aspek pembatas (hedge) lebih banyak digunakan dalam ranah kampus. Sedangkan dalam aspek tingkat tutur, hanya mahasiswa Jawa dan Madura saja yang menggunakannya.
\end{abstract}

Kata kunci: tindak tutur direktif, kesantunan, mahasiswa multikultural

To cite this article:

Hadiwijaya, M., Amalyasari, M. R., \& Yahmun. (2021). Penggunaan Tindak Tutur Direktif Mahasiswa Multikultural dalam Konteks Kesantunan. Diglosia: Jurnal Kajian Bahasa, Sastra, dan Pengajarannya, 4(4), 413424. https://doi.org/10.30872/diglosia.v4i4.230 


\section{A. PENDAHULUAN}

Ikatan primordial berperan sangat vital dalam membentuk cara pandang seseorang terhadap sesuatu hal. Cara pandang seseorang yang datang dari keluarga pesantren misalnya akan sangat berbeda dengan mereka yang lahir dan dibesarkan dari keluarga pengusaha dalam memaknai bunga bank. Seseorang yang berasal dari suku tertentu mungkin memiliki pandangan berbeda dengan mereka yang berasal dari suku lain mengenai konsep kesantunan dalam ujaran, dan sebagainya. Hal ini sangat menarik untuk dicermati jika dalam satu komunitas memiliki ikatan primordial yang berbeda-beda, yang lazim disebut masyarakat multikultural.

Tentu dalam berkomunikasi, penutur harus mampu memahami situasi dan memilih ujaran yang cocok untuk mitra tuturnya agar konflik bisa dihindari. Memahami pola masing-masing gaya berkomunikasi anggota masyarakat adalah penting untuk dilakukan (Hadiwijaya \& Yahmun, 2017). Berbeda suku berbeda pula budaya, kebiasaan, maupun norma yang berlaku. Terkadang hal yang dianggap pantas di suatu masyarakat belum tentu dianggap sama di masyarakat yang lain, atau sebaliknya. Oleh karenanya, peribahasa di mana bumi dipijak, di situ langit dijunjung yang berarti sebagai anggota sebuah masyarakat kita harus menghormati adat istiadat yang berlaku dalam masyarakat tersebut., sangat penting untuk diimplementasikan. Hal ini menarik ketika anggota masyarakat tersebut bukan penduduk asli/pendatang, di mana sejak lahir sudah tertanam budaya, norma maupun kebiasaan yang diperoleh dari daerah asalnya. Sebagian mungkin sangat memegang erat aturan-aturan tersebut, dan sebagian lagi mungkin abai, dalam situasi ini persilangan budaya tidak dapat dihindarkan (Liliweri, 2005).

Fungsi utama dari bahasa sebagai alat komunikasi memiliki dua dimensi yang berbeda. Dimensi pertama bahasa sebagai alat penyampai informasi dan pesan yang disebut fungsi transaksional dan sebagai alat penjaga hubungan sosial antar penuturnya. Artinya dalam berkomunikasi menyampaikan pesan saja tidaklah cukup, melainkan harus memperhatikan dimensi interaksi sosial agar komunikasi tersebut dapat berjalan dengan baik dan lancar. Dalam kajian Sosiolinguistik, hubungan antara dua dimensi ini dijelaskan dengan tiga pokok konsep komunikasi,, yaitu kesantunan, kerja sama, dan tindak tutur (Wardhaugh \& Fuller, 2006).

Konsep kesantunan yang merupakan "jantung" dari ke tiga pilar komunikasi di atas, merupakan cerminan dari seorang penutur, baik buruk seseorang salah satunya dapat dilihat dari kesantunan yang dimilikinya. Dalam konteks masyarakat multikultural, tentu saja hal ini memberikan tantangan tersendiri bagi kaum pendatang. Tidak hanya harus menyesuaikan dengan norma serta aturan yang berlaku dalam masyarakat yang baru, melainkan juga harus memilah norma dan kebiasaan bawaan yang bertentangan. Inti dari kesantunan berbahasa adalah meminimalisir Face Threatening Acts (FTA) sebuah konsep yang diperkenalkan oleh Brown \& Levinson (1988), yaitu tindakan yang berpotensi untuk mengancam martabat mitra tutur. Dalam menggunakan tindak tutur direktif permintaan, misalnya, bagaimana meminta sesuatu tanpa harus merepotkan atau menyinggung mitra tutur haruslah disertai dengan penggunaan perangkat kesantunan, seperti honorifik, pembatas (hedge), ataupun tingkat tutur untuk meminimalisir terjadinya FTA (Kroeger, 2018).

Tindak tutur direktif permintaan adalah salah satu jenis tindak tutur yang berfungsi agar mitra tutur melakukan sesuatu yang diminta oleh penutur. Tindak tutur merupakan teori yang dikembangkan oleh Austin (1962) dan Searle (1969) 
dalam (Yule, 1996). Konsep tindak tutur, yang didefinisikan sebagai melakukan tindakan melalui ujaran, membagi ujaran menjadi lima jenis ujaran, yaitu Representatif, Direktif, Ekspresif, Komisif, dan Deklaratif. Tindak tutur representatif mengikat mitra tutur terhadap kebenaran yang disampaikan penutur; tindak tutur direktif berfokus pada bagaimana mitra tutur melakukan apa yang diminta oleh penutur; tindak tutur ekspresif merupakan evaluasi tentang hal yang disebutkan di dalam tuturan itu; komisif mengikat penutur untuk melakukan sesuatu; sedangkan terakhir deklaratif berfokus pada penciptaan keadaan yang baru dengan ujaran (Barron, 2017).

Penggunaan tindak tutur, dalam implementasinya, sangat bergantung pada situasi dan kondisi mitra tutur. Tindak tutur tidak bisa terlepas dari dimensi sosial mitra tuturnya, oleh karenanya, setiap pengungkapan tindak tutur harus didasari oleh kesantunan berbahasa (Dwi \& Zulaeha, 2017). Penelitian ini berfokus pada penggunaan tindak tutur direktif mahasiswa multikultural dalam konteks kesantunan yang belajar di Kota Malang. Terdapat lima suku yang menjadi subjek dari penelitian ini, yaitu Jawa, Sumba, Flores, Dayak, dan Madura. Bagaimana mereka menggunakan ujaran direktif permintaan dalam situasi yang berbeda baik dalam ranah keluarga, pertemanan, maupun ranah sekolah dan bagaimana mereka meminimalisir FTA yang mungkin terjadi ketika menghadapi mitra tutur yang berbeda, adalah aspek-aspek yang akan diungkap dalam penelitian ini.

\section{B. METODE}

Penelitian ini menggunakan metode deskriptif kualitatif. Data diperoleh dari 100 mahasiswa yang berasal dari lima suku berbeda, yaitu: Jawa, Sumba, Flores, Dayak, dan Madura, setiap suku diwakili oleh 20 mahasiswa. Data dikumpulkan dengan menggunakan tiga instrumen penelitian yaitu penyebaran angket, wawancara, dan observasi langsung interaksi mereka yang terjadi di kampus. Langkah-langkah analisa data penelitian ini menggunakan tiga tahapan analisa data Miles \& Huberman (1999). Data direduksi disesuaikan dengan tujuan dari penelitian ini kemudian dikelompokkan dan dianalisis berdasarkan bagaimana mereka menggunakan ujaran direktif permintaan dalam situasi yang berbeda baik dalam ranah keluarga, pertemanan, maupun ranah sekolah dan bagaimana mereka meminimalisir FTA yang mungkin terjadi ketika menghadapi mitra tutur yang berbeda, seperti terlihat dalam tabel di bawah ini. Yang didasarkan pada perangkat kesantunan yang diadaptasi dari teori kesantunan Brown \& Levinson (1988), dengan skema sebagai berikut.

Tabel 1. Perangkat Kesantunan untuk Meminimalisir FTA

\begin{tabular}{|c|c|c|c|c|c|c|c|}
\hline \multirow{2}{*}{ No. } & \multirow{2}{*}{ Suku } & \multirow{2}{*}{ Istilah } & \multirow{2}{*}{ Perangkat } & \multicolumn{4}{|c|}{ Mitra Tutur dan Situasi } \\
\hline & & & & $+\mathbf{P}+\mathrm{S}$ & $+\mathrm{P}-\mathrm{S}$ & $-\mathbf{P}+\mathbf{S}$ & Situasi \\
\hline \multirow[t]{4}{*}{1.} & & & Langsung & & & & \\
\hline & & & Honorifik & & & & \\
\hline & & & Pembatas & & & & \\
\hline & & & Tingkat tutur & & & & \\
\hline
\end{tabular}


Kolom pertama berisi tentang informasi suku dari objek penelitian, kolom ke dua berisi tentang istilah-istilah ujaran direktif permintaan dalam bahasa daerah yang digunakan oleh objek penelitian, kolom ke tiga berisi tentang perangkat kesantunan yang digunakan sebagai indikator tingkat kesantunan, dan kolom terakhir berisikan informasi tentang mitra tutur dan situasinya. Mitra tutur dalam penelitian ini dibagi atas tiga kategori, yaitu $+\mathrm{P}+\mathrm{S}$ yang berarti penutur menghormati dan akrab dengan mitra tutur; $+\mathrm{P}-\mathrm{S}$, yang berarti penutur menghormati tetapi tidak akrab dengan mitra tutur; $-\mathrm{P}+\mathrm{S}$, yang berarti penutur tidak menghormati tetapi akrab dengan mitra tutur. Sedangkan situasi dibedakan menjadi dua, yaitu formal (F) dan informal (I).

Setelah data dikelompokkan dan dianalisis, selanjutnya ditarik kesimpulan sementara tentang penggunaan tindak tutur direktif mahasiswa multikultural yang belajar di Kota Malang dalam konteks kesantunan masing-masing suku. Berdasarkan kesimpulan-kesimpulan sementara ini, kesimpulan akhir dapat diperoleh.

\section{PEMBAHASAN}

Dalam bagian ini akan dipaparkan hasil dan pembahasan analisa data dari penelitian ini,, yaitu penggunaan tindak tutur direktif mahasiswa multikultural dalam konteks kesantunan.

Tabel 2. Tindak Tutur Direktif Mahasiswa Multikultural di Kota Malang Berdasarkan Hubungan Power (P) dan Solidarity (S)

\begin{tabular}{|c|c|c|c|c|c|c|c|}
\hline \multirow{2}{*}{ No. } & \multirow{2}{*}{ Suku } & \multirow{2}{*}{ Istilah } & \multirow{2}{*}{ Perangkat } & \multicolumn{4}{|c|}{ Mitra Tutur dan Situasi } \\
\hline & & & & $+\mathrm{P}+\mathrm{S}$ & $+\mathrm{P}-\mathrm{S}$ & $-\mathbf{P}+\mathbf{S}$ & Situasi \\
\hline \multirow[t]{4}{*}{1.} & \multirow[t]{4}{*}{ Jawa } & \multirow{4}{*}{$\begin{array}{l}\text { Nedhi, nyuwun, nyambut, } \\
\text { jaluk, mau, minta, badhe, } \\
\text { minta, meminta }\end{array}$} & Langsung & $100 \%$ & $100 \%$ & $100 \%$ & $\mathrm{~F} / \mathrm{IF}$ \\
\hline & & & Honorifik & $95 \%$ & $100 \%$ & $60 \%$ & $\mathrm{~F} / \mathrm{IF}$ \\
\hline & & & Pembatas & $95 \%$ & $100 \%$ & $30 \%$ & $\mathrm{~F} / \mathrm{IF}$ \\
\hline & & & Tingkat tutur & $60 \%$ & $70 \%$ & $70 \%$ & IF \\
\hline \multirow[t]{4}{*}{2.} & \multirow[t]{4}{*}{ Sumba } & \multirow{4}{*}{$\begin{array}{l}\text { kyreyo, bagi, mbaku, bisa, } \\
\text { denggi, yodi, tolong bantu, } \\
\text { wanda, tolong wo'i, bantu, } \\
\text { bisa pinjam, yaki, haromu }\end{array}$} & Langsung & $100 \%$ & $100 \%$ & $100 \%$ & $\mathrm{~F} / \mathrm{IF}$ \\
\hline & & & Honorifik & $80 \%$ & $100 \%$ & $30 \%$ & $\mathrm{~F} / \mathrm{IF}$ \\
\hline & & & Pembatas & $80 \%$ & $100 \%$ & - & $\mathrm{F} / \mathrm{IF}$ \\
\hline & & & Tingkat tutur & - & - & - & $\mathrm{F} / \mathrm{IF}$ \\
\hline \multirow[t]{4}{*}{3.} & \multirow[t]{4}{*}{ Flores } & \multirow{4}{*}{$\begin{array}{l}\text { ahe, letta, ngala bantu, } \\
\text { ngance selong laku, dahuq, } \\
\text { tegi, minta, pinjam, dan } \\
\text { belikan }\end{array}$} & Langsung & $100 \%$ & $100 \%$ & $100 \%$ & $\mathrm{~F} / \mathrm{IF}$ \\
\hline & & & Honorifik & $95 \%$ & $100 \%$ & - & $\mathrm{F} / \mathrm{IF}$ \\
\hline & & & Pembatas & $15 \%$ & $80 \%$ & - & $\mathrm{F} / \mathrm{IF}$ \\
\hline & & & Tingkat tutur & - & - & - & $\mathrm{F} / \mathrm{IF}$ \\
\hline \multirow[t]{4}{*}{4.} & \multirow{4}{*}{$\begin{array}{l}\text { Dayak } \\
\text { Ahe }\end{array}$} & \multirow{4}{*}{$\begin{array}{l}\text { minta', mantu', nolong, } \\
\text { minjam', pinjam, minta } \\
\text { tolong, bantu, }\end{array}$} & Langsung & $100 \%$ & $100 \%$ & $100 \%$ & $\mathrm{~F} / \mathrm{IF}$ \\
\hline & & & Honorifik & $95 \%$ & $100 \%$ & - & $\mathrm{F} / \mathrm{IF}$ \\
\hline & & & Pembatas & - & $100 \%$ & - & $\mathrm{F} / \mathrm{IF}$ \\
\hline & & & Tingkat tutur & - & - & - & $\mathrm{F} / \mathrm{IF}$ \\
\hline \multirow[t]{4}{*}{5.} & \multirow[t]{4}{*}{ Madura } & \multirow{4}{*}{$\begin{array}{l}\text { menta, nyoonah, nyatoa, } \\
\text { minta'ah, mintah nyabut, } \\
\text { ngenjhem, tolong, minta, } \\
\text { pinjam, nginjemmah }\end{array}$} & Langsung & $100 \%$ & $100 \%$ & $100 \%$ & $\mathrm{~F} / \mathrm{IF}$ \\
\hline & & & Honorifik & $95 \%$ & $100 \%$ & $30 \%$ & $\mathrm{~F} / \mathrm{IF}$ \\
\hline & & & Pembatas & $80 \%$ & $90 \%$ & $25 \%$ & $\mathrm{~F} / \mathrm{IF}$ \\
\hline & & & Tingkat tutur & $60 \%$ & $80 \%$ & - & $\mathrm{F} / \mathrm{IF}$ \\
\hline
\end{tabular}


Tabel di atas menunjukkan tindak tutur yang digunakan oleh para mahasiswa multikultural dalam interaksinya dengan mitra tutur yang memiliki $\mathrm{P}$ dan $\mathrm{S}$ berbeda dan diksi-diksi yang digunakan. Enam suku menjadi subjek dalam penelitian ini, yaitu: mahasiswa Jawa, mahasiswa Sumba, mahasiswa Flores, mahasiswa Dayak, dan mahasiswa Madura. Terdapat empat situasi $\mathrm{P}$ dan $\mathrm{S}$ dalam penelitian ini, $+\mathrm{P}+\mathrm{S}$, yang berarti penutur menghormati dan akrab dengan mitra tutur; $+\mathrm{P}-\mathrm{S}$, yang berarti penutur menghormati tetapi tidak akrab dengan mitra tutur; $-\mathrm{P}+\mathrm{S}$, yang berarti penutur tidak menghormati tetapi akrab dengan mitra tutur; dan terakhir, $\mathrm{F}$ yang berarti formal. Tindak tutur yang menjadi fokus dari penelitian ini terbatas hanya pada tiga jenis ujaran yaitu direktif, komisif dan ekspresif. Dari tiga jenis ujaran ini diteliti penggunaannya berdasarkan empat kriteria, yaitu penggunaan ekspresi langsung atau tidak langsung, penggunaan honorifik, penggunaan pembatas (hedging), dan tingkatan bahasanya.

\section{Tindak Tutur Direktif Permintaan Langsung dan Tidak Langsung}

Dalam tindak tutur direktif, tuturan penutur dimaksudkan untuk menyuruh orang lain melakukan sesuatu sesuai dengan kehendak penutur. Terdapat dua jenis tindak tutur menurut Nadar dalam (Astuti, 2019) yaitu tindak tutur langsung dan tidak langsung. Tindak tutur langsung terjadi apabila modus dan ujaran yang digunakan sesuai. Dengan kata lain bentuk ujaran yang digunakan oleh penutur selaras dengan fungsi dari bentuk ujaran tersebut. Sebaliknya, tindak tutur tidak langsung terjadi apabila modus dan ujaran yang digunakan tidak terdapat kesesuaian, antara bentuk ujaran dan fungsinya tidak berhubungan.

Fokus penelitian ini adalah tindak tutur direktif permintaan yang digunakan oleh para mahasiswa dari lima suku berbeda yang belajar di Kota Malang dalam konteks kesantunan. Berikut dipaparkan temuan tindak tutur yang digunakan oleh para mahasiswa dari suku yang berbeda dalam interaksinya dengan mitra tutur dan situasi yang berbeda.

Ujaran direktif berupa permintaan yang sering digunakan oleh mahasiswa Jawa antara lain sebagai berikut: Nedhi, nyuwun, nyambut, jaluk, mau, minta, badhe, minta, meminta. Beberapa diksi tersebut berbeda-beda tergantung mitra tutur dan situasi yang melandasi interaksi tersebut. Dari tabel di atas dapat diketahui bahwa dalam berinteraksi dengan mitra tutur dan situasi yang berbeda para mahasiswa Jawa menggunakan ujaran langsung. Dari 20 mahasiswa Jawa yang menjadi subjek dalam penelitian ini, semua menggunakan ujaran langsung dalam menyampaikan permintaannya, baik ke sejawat, orang tua yang mereka hormati dan akrab, maupun orang yang mereka hormati tetapi tidak akrab. Dalam teori kesantunan berbahasa yang dicetuskan Brown \& Levinson (1988) penggunaan ujaran tidak langsung (offrecord) merupakan bentuk kesantunan yang tinggi karena ketidaklangsungan ujaran yang digunakan menghindarkan penutur bersentuhan langsung dengan FTA (Face Threatening Act).

Salah satu keunikan bangsa Indonesia adalah kekayaannya akan suku dan Bahasa. Terdapat sekitar 671 bahasa yang dimiliki suku-suku yang ada di Indonesia. Wilayah yang memiliki suku dan Bahasa terbanyak di Indonesia adalah wilayah Indonesia timur. Nusa Tenggara Timur (NTT) memiliki hampir 68 bahasa yang tersebar di pulau-pulau yang menjadi wilayahnya, seperti Sumba, Flores, Timor Barat, dan lain-lain. Sumba yang merupakan salah satu pulau terbesar di NTT terbagi menjadi empat kabupaten dan memiliki hanya satu Bahasa yaitu Bahasa Sumba 
dengan berbagai macam dialek (Soeriadiredja, 2013). Meskipun dikatakan demikian akan tetapi pada kenyataannya dialek-dialek yang mereka gunakan tidak memenuhi kaidah 'saling berpaham' (mutual intelligibility). Antara suku-suku asli Sumba yang berbeda-beda yang mendiami pulau sumba tidak memiliki pemahaman yang sama ketika mereka berinteraksi dengan dialek yang berbeda. Artinya secara teori, dialekdialek yang digunakan oleh masyarakat Sumba adalah Bahasa-bahasa daerah yang berbeda yang diturunkan dari Bahasa asli mereka yaitu Bahasa Sumba. Penelitian ini menguatkan asumsi tersebut, bahwa dari 20 mahasiswa Sumba yang berasal dari empat kabupaten berbeda yang menjadi subjek dari penelitian ini, terdapat beberapa Bahasa yang mereka gunakan dalam berinteraksi. Mahasiswa Sumba Barat, suku Loli, misalnya, menggunakan istilah kyreyo untuk mengungkapkan ujaran tindak tutur direktif permintaan, sedangkan mahasiswa Sumba Timur menggunakan istilah wanda dan karainggunya, dan ketika mereka berinteraksi Bahasa Indonesia dialek timur lah yang mereka gunakan.

Tindak tutur direktif permintaan yang lazim digunakan oleh para mahasiswa Sumba cukup bervariasi diksinya, tergantung suku mereka. Beberapa di antaranya sebagai berikut: kyreyo, bagi, mbaku, bisa, denggi, yodi, tolong bantu, wanda, tolong wo'i, bantu, bisa pinjam, yaki, haromu. Ujaran tindak tutur diraktif langsung digunakan mahasiswa Sumba ketika meminta sesuatu baik kepada mitra tutur $+\mathrm{P}+\mathrm{S},+\mathrm{P}-\mathrm{S}$, ataupun $-\mathrm{P}+\mathrm{S}$, di situasi formal maupun non-formal.

Mahasiswa berasal dari Flores memiliki jumlah populasi yang cukup besar di Kota Malang. Flores adalah salah satu pulau terbesar yang dimiliki oleh Provinsi NTT. Di pulau ini terdapat sepuluh Bahasa yang mempunyai pengguna cukup banyak, di antaranya: Lamaholot, Kedang, Nagi, Sika, Palue, Lio, Ngada, Rembong, Manggarai, dan Komodo. Satu Bahasa yang ada di Flores biasanya memiliki dialek yang sangat berbeda antara Kecamatan satu dengan lainnya, oleh karenanya dialek yang dimiliki satu Bahasa sangatlah beragam. Bahasa Lamaholot, misalnya, yang menjadi Bahasa masyarakat Flores Timur dan kepulauan Solor, memiliki 7-8 dialek dalam satu kecamatan. Bisa dibayangkan betapa kaya ragam dialek dalam Bahasa Lamaholot karena di Kabupaten Flores Timur memiliki kurang lebih 19 Kecamatan (Nagaya, 2011).

Penelitian ini memperoleh data dari 20 mahasiswa Flores yang belajar di Kota Malang yang menggunakan Bahasa daerah yang berbeda-beda. Dalam situasi formal maupun informal $100 \%$ dari mereka menggunakan ujaran tindak tutur direktif langsung untuk menyampaikan permintaan mereka, baik dalam Bahasa daerah maupun Bahasa Indonesia, baik dengan mitra tutur $+\mathrm{P}+\mathrm{S},+\mathrm{P}-\mathrm{S}$, dan $-\mathrm{P}+\mathrm{S}$. Ujaran direktif yang sering mereka gunakan dalam interaksi mereka antara lain: 'ahe, letta, ngala bantu, ngance selong laku, dahuq, tegi, minta, pinjam, dan belikan'.

Kalimantan merupakan pulau terbesar yang ada di Indonesia. Dengan wilayah yang sangat luas, Kalimantan memiliki kurang lebih 139 bahasa daerah. Salah satu rumpun Bahasa terbesar di Kalimantan adalah Dayak Darat yang banyak digunakan oleh masyarakat yang mendiami daerah Kalimantan Barat. Terdapat kurang lebih 16 bahasa yang termasuk dalam rumpun Dayak Darat. Populasi mahasiswa yang berasal Kalimantan Barat yang belajar di Kota Malang cukup besar. Data dari penelitian ini yang berupa ujaran-ujaran tindak tutur direktif permintaan baik dalam Bahasa daerah maupun Bahasa Indonesia diambil dari 20 mahasiswa Kalimantan Barat yang belajar di Kota Malang. Para mahasiswa tersebut masing-masing berasal dari suku Dayak Ahe, Dayak Bekati, Melayu, dan Jangkang (Yulianti, 2017). 
Dalam mengungkapkan tindak tutur direktif permintaan, secara umum, terdapat beberapa ujaran yang umum digunakan oleh para mahasiswa Kalimantan. Ujaran-ujaran tersebut sangat bergantung pada situasi dan mitra tutur yang mendasari interaksi yang terjadi. Istilah-istilah, seperti 'minta', mantu', nolong, minjam' sering digunakan ketika mereka mengungkapkan tindak tutur direktif permintaan dalam situasi non formal. Dalam situasi formal, diksi-diksi tindak tutur direktif permintaan dalam Bahasa Indonesia, seperti 'pinjam, minta tolong, bantu, dan sebagainya, sering digunakan. Bahasa-bahasa yang digunakan oleh masyarakat Kalimantan Barat berasal dari rumpun Malayic-Dayak, oleh karenanya kosakata yang ada dalam beberapa Bahasa daerah ini sangat kental dipengaruhi oleh Bahasa Melayu. Pola penggunaan tindak tutur direktif oleh mahasiswa Kalimantan umumnya bersifat langsung, dengan siapa pun mereka berinteraksi dan dalam situasi apa pun.

Jumlah mahasiswa yang berasal dari daerah berbahasa Madura memiliki proporsi yang cukup banyak di Kota Malang. Mahasiswa berbahasa Madura yang belajar di Kota Malang tidak hanya berasal dari pulau Madura tetapi juga berasal dari berbagai kota di Jawa Timur yang menggunakan bahasa Madura sebagai bahasa ibu dan bahasa interaksi mereka, seperti Probolinggo, Pasuruan, Situbondo dan sebagainya Di Kota Malang sendiri terdapat beberapa daerah yang sebagian besar masyarakatnya berbahasa Madura, seperti Kelurahan Mergosono, Kelurahan Kota Lama, Kelurahan Jodipan, dan sebagainya.

Penelitian ini menggunakan 20 mahasiswa yang berbahasa ibu bahasa Madura sebagai subjek untuk mengetahui implementasi penggunaan ujaran tindak tutur direktif permintaan dalam interaksi mereka baik di ranah keluarga, pertemanan, maupun sekolah/ kampus, dengan tiga kategori mitra tutur, $+\mathrm{P}+\mathrm{S},+\mathrm{P}-\mathrm{S}$, dan $-\mathrm{P}+\mathrm{S}$. Didapatkan bahwa terdapat kecenderungan para mahasiswa berbahasa Madura dalam menggunakan jenis ujaran ini secara langsung dengan menggunakan diksidiksi seperti menta, nyoonah, nginjemmah, nyatoa, minta'ah, mintah nyabut, ngenjhem, tolong, minta, pinjam dan sebagainya Penggunaan ragam ujaran sindiran ataupun kiasan sangat jarang mereka gunakan baik di ranah keluarga, pertemanan, ataupun kampus.

\section{Honorifik}

Menurut Yule dalam Alfi \& Rosita (2019) kesantunan merupakan alat untuk menunjukkan kesadaran muka orang lain dalam sebuah interaksi. Konsep muka yang merujuk pada citra diri seseorang menjadi sentral dalam penggunaan kesantunan. Salah satu strategi dalam menjaga muka negatif seseorang adalah dengan memberikan penghormatan, yang salah satu bentuknya adalah penyebutan honorifik. Honorifik adalah istilah untuk aspek-aspek struktur bahasa yang menyandikan identitas sosial peserta, atau hubungan sosial di antara mereka, atau antara salah satu dari mereka dan orang atau entitas yang disebut dalam peristiwa komunikasi (Brown, 2011; Brown \& Levinson, 1988).

Penyebutan honorifik yang juga merupakan penanda dari kesantunan sering kali digunakan oleh para mahasiswa Jawa ketika berbicara dengan orang yang mereka hormati baik akrab maupun tidak. Dalam konteks berbicara dengan sejawat mereka jarang atau tidak pernah menggunakan honorifik. Terdapat temuan dalam penelitian ini yang menyatakan bahwa hanya $5 \%$ yang tidak menggunakan honorifik ketika berbicara dengan orang yang mereka hormati dan akrab. Artinya secara 
umum para mahasiswa Jawa menggunakan honorifik untuk menunjukkan kesopanannya dalam ujaran direktif. Penyebutan seperti bapak, ibu, paklik, bulik, dan sebagainya. Sangat sering digunakan ketika berinteraksi dengan mitra tutur yang mereka hormati baik akrab maupun tidak.

Penggunaan honorifik ketika menghadapi mitra tutur $+\mathrm{P}+\mathrm{S}$ oleh para mahasiswa Sumba memiliki persentase sebesar $80 \%$. Penyebutan sapaan seperti loka, bbi, tuya, lili, mamu lazim digunakan dalam mengungkapkan tindak tutur direktif permintaan kepada mitra tutur yang mereka hormati dan akrab. Dari 20 mahasiswa Sumba, semua, menggunakan honorifik ketika meminta sesuatu kepada orang yang mereka hormati tetapi kurang akrab, seperti guru atau dosen. Penyebutan 'Pak/Ibu guru' selalu mereka gunakan. Sementara 30\% dari mereka ketika meminta sesuatu ke sejawat menggunakan honorifik, dengan menggunakan istilah-istilah sebagai berikut, yang kesemuanya memiliki arti, teman atau saudara 'angua, oda, tema'.

Hampir sama dengan tetangga pulaunya, Sumba, banyak Bahasa yang ada di pulau Flores tidak mengenal ragam Bahasa yang memiliki tingkatan kesantunan. Oleh karenanya seperti halnya Bahasa Indonesia, bentuk kesantunan yang dipergunakan antara lain adalah melalui penyebutan honorifik terhadap mitra tutur yang dihadapi. Dalam situasi formal di mana kebanyakan mereka menggunakan Bahasa Indonesia, 100\% mereka menggunakan honorifik, ketika berinteraksi dengan mitra tutur yang mereka hormati dan akrab maupun tidak, penyebutan 'Pak Guru, Bu Guru, Bapak, Ibu, Prof, dll.' lazim mereka gunakan bersama tindak tutur direktif permintaan untuk menunjukkan kesantunan berbahasa mereka,, seperti 'Bapak tolong ajar saya bahasa Inggris dulu, karena mata pelajaran itu sangat sulit'. Dalam berbagai Bahasa daerah mereka ketika menyampaikan tindak tutur direktif permintaan 95\% mereka menggunakan honorifik seperti: bapa besar, nana/bibi, tata/eda, opu, tanta, inang, paman, om, bibi, guru, tata guru, dan sebagainya.

Terhadap mitra tutur yang berbeda, mahasiswa Kalimantan menggunakan honorifik untuk menunjukkan kesantunan mereka. Dalam berinteraksi dengan mitra tutur $+\mathrm{P}+\mathrm{S}, 95 \%$ dari mereka menggunakan honorifik. Sebutan seperti Mak/uwe', Bi/om, Wak, Mak long/ Pak long, adalah sebutan-sebutan honorifik yang lazimnya digunakan dalam interaksi ranah keluarga. Sedangkan dalam ranah sekolah dan masyarakat, dengan mitra tutur $+\mathrm{P}-\mathrm{S}, 100 \%$ mahasiswa yang menjadi subjek penelitian ini menyatakan menggunakan panggilan honorifik, seperti Bapak/Ibu, Pak guru/Ibu guru, dan sebagainya Dalam ranah pertemanan, -P-S, hanya $20 \%$ dari mereka yang berinteraksi dengan menggunakan honorifik untuk menyapa teman dengan penyebutan 'kawan'.

Ujaran direktif permintaan dalam teori kesantunan (Leech, 2014), jika tidak ada usaha dalam meminimalisir FTA, telah melanggar dua bidal sekaligus, yaitu bidal kebijaksanaan dan bidal kedermawanan. Penitikberatan dua bidal tersebut terletak pada memaksimalkan keuntungan dan meminimalkan kerugian mitra tutur. Upaya meminimalisir FTA pada ujaran ini dapat dilakukan dengan menambahkan sebutan honorifik dan pembatas (hedge). Dalam penelitian ini, para mahasiswa berbahasa Madura di ranah keluarga, dengan mitra tutur $+\mathrm{P}+\mathrm{S}, 95 \%$ dari mereka menggunakan honorifik, seperti $b i$, paman, man, pak, buk, dan sebagainya. Dalam ranah masyarakat, dan sekolah ketika meminta sesuatu kepada mitra tutur + P-S, $100 \%$ dari mereka menggunakan penyebutan honorifik, seperti Prof, Pak, Bu, Ji, dan sebagainya. Sedangkan dalam ranah pertemanan dengan mitra tutur -P+S, 30\% dari mereka menggunakan sebutan keakraban "Cong" atau kanak. 


\section{Pembatas (Hedging)}

Pembatas (hedging) juga sering digunakan untuk menunjukkan kesantunan, seperti yang diungkapkan oleh Brown \& Levinson (1988). Perangkat pembatas menjadi penanda kesantunan berdasarkan asumsi bahwa semakin Panjang ujaran yang digunakan dalam berinteraksi semakin santun pula anggapan mitra tutur.

Dalam penelitian ini ditemukan bahwa sedikit sekali para mahasiswa Jawa yang menggunakan perangkat pembatas dalam ujaran direktif permintaan mereka. Hanya terdapat 5\% mahasiswa yang menggunakan pembatas ketika berbicara dengan orang yang mereka hormati dan akrab, dan 30\% ketika berbicara dengan mitra tutur yang mereka hormati tetapi tidak akrab. Pembatas yang sering mereka gunakan adalah kata "nuwun sewu" (permisi), yang biasanya diikuti dengan penyebutan honorifik, $P a k, B u, P a k l i k$, dan sebagainya

Penggunaan pembatas (hedging) juga sulit ditemukan dalam interaksi para mahasiswa Sumba dengan tiga mitra tutur yang berbeda di atas. Akan tetapi dalam situasi formal seperti di kampus/ sekolah, ketika dituntut untuk menggunakan Bahasa Indonesia, 50\% dari mereka menggunakannya untuk kesantunan. Ungkapan pembatas yang sering digunakan adalah 'maaf mengganggu dan permisi' ketika mereka menyatakan permintaan kepada mitra tutur $+\mathrm{P}-\mathrm{S}$.

Pembatas juga digunakan oleh para mahasiswa Flores baik ketika berinteraksi dengan mitra tutur yang berbeda maupun situasi yang berbeda. Dalam Bahasa daerah, penelitian ini menunjukkan penggunaan pembatas memiliki porsi yang cukup kecil, 15\%. Ungkapan seperti 'ngance tegi nganceng, mok tolong' kadang kala digunakan mahasiswa Flores dalam interaksi mereka dengan mitra tutur yang mereka hormati tetapi tidak akrab. Sedangkan dalam situasi formal, 20\% mereka terbiasa menggunakan pembatas kepada mitra tutur yang mereka hormati baik yang akrab maupun tidak dengan mengawali tindak tutur direktif permintaan mereka dengan ungkapan seperti maaf dan permisi.

Salah satu ciri khas masyarakat Kalimantan dalam berkomunikasi adalah menyampaikan sesuatu secara langsung pada poin yang dituju. Meskipun demikian, tetap ada basa basi untuk kesantunan ketika menyampaikan ujaran tindak tutur direktif, dengan menggunakan pembatas ketika mereka menghadapi mitra tutur $+\mathrm{P}-$ $\mathrm{S}$, dalam ranah interaksi sekolah dan masyarakat. Penelitian ini mengungkap bahwa dalam interaksi sekolah dan masyarakat, para mahasiswa Kalimantan 100\% menggunakan pola pembatas untuk kesantunan dalam Bahasa Indonesia, seperti permisi, maaf, terima kasih, dan lain sebagainya. Hal ini sangat berbeda ketika mereka berinteraksi dalam ranah keluarga dan pertemanan, yang lebih cenderung langsung pada poin yang dituju. Ujaran seperti "Wak ngantet ko no pasar ru tam." (Paman/Bibi antar saya ke pasar dulu ya), sangat lazim digunakan dalam menyampaikan sebuah permintaan.

Pembatas sering digunakan para mahasiswa berbahasa Madura untuk menunjukkan kesantunan mereka. Ungkapan yang sering digunakan dalam memperhalus ujaran direktif permintaan antara lain "Saporanah, (honorifik), cangkolang, manabi ngakungih (benda yang diinginkan)" yang artinya maaf, (honorifik), lancang, jika punya (benda yang diinginkan). Diperoleh bahwa 80\% mahasiswa berbahasa Madura menggunakan ungkapan di atas untuk meminimalisir FTA ketika meminta sesuatu kepada mitra tutur $+\mathrm{P}+\mathrm{S}$. Terhadap mitra tutur $+\mathrm{P}-\mathrm{S}$, dalam ranah masyarakat dan sekolah, adalah 90\%. Sedangkan dengan mitra tutur - 
$\mathrm{P}+\mathrm{S}, 35 \%$ dari mereka menggunakan pembatas akan tetapi menggunakan ragam bahasa Madura kasar.

\section{Tingkat Tutur}

Dalam bahasa Jawa terdapat tiga tingkatan ragam Bahasa yang disebut undha usuk yang merupakan ragam Bahasa yang digunakan oleh penutur Jawa untuk menunjukkan kesantunan mereka terhadap mitra tutur yang dihadapi. Semakin penutur menghormati mitra tutur semakin tinggi ragam Bahasa Jawa yang akan ia gunakan. Akan tetapi sekarang asumsi tersebut lambat tapi pasti mulai memudar (Asmorotedjo, 2019; Suryadi et al., 2014). Banyak mahasiswa Jawa yang lebih nyaman menggunakan Bahasa Indonesia ketika berinteraksi dengan mitra tutur yang mereka hormati. Mereka merasa lebih aman menggunakan Bahasa Indonesia karena dianggap lebih netral. Terdapat beberapa alasan mengapa mereka memilih Bahasa Indonesia daripada ragam Bahasa Jawa yang lebih halus. Tidak bisa/ minimnya pengetahuan tentang ragam Bahasa Jawa halus dan untuk menghindari kerepotan yang mungkin terjadi jika mereka menggunakan ragam Bahasa Jawa yang lebih tinggi. Penelitian ini menunjukkan bahwa 60\% mahasiswa Jawa masih menggunakan ragam Bahasa Jawa halus ketika mereka berinteraksi dengan mitra tutur yang dihormati dan akrab dan $70 \%$ ketika berinteraksi dengan mitra tutur yang dihormati tetapi tidak akrab. Selebihnya mereka menggunakan ragam Bahasa Jawa kasar dan Bahasa Indonesia. Di lingkungan formal seperti kampus, dalam interaksinya dengan dosen dan mahasiswa lain yang satu suku ataupun lain $70 \%$ dari mereka menggunakan Bahasa Indonesia, sisanya menggunakan ragam Bahasa Jawa ngoko dan madya.

Terdapat satu kesamaan yang dimiliki oleh para mahasiswa Sumba, dari suku apa pun mereka, yaitu berkaitan dengan ragam tingkatan Bahasa santun. Dari beberapa suku yang ada di pulau Sumba tidak satu pun yang memiliki sistem ragam tingkatan Bahasa seperti yang dimiliki Bahasa Jawa maupun Madura. Oleh karena dalam setiap situasi dengan mitra tutur yang berbeda tingkatan mereka menggunakan ragam Bahasa yang sama. Dalam mengungkapkan permintaan, mereka menggunakan diksi yang sama dengan menambahkan honorifik dan beberapa dengan pembatas untuk menunjukkan kesantunan mereka. Dalam situasi formal seperti di sekolah ataupun kampus, hanya 10\% mereka menggunakan Bahasa daerah ketika berkomunikasi dengan mitra tutur yang mereka hormati dan akrab. Sedangkan ketika berinteraksi dengan mitra tutur yang mereka hormati tetapi kurang akrab, 100\% dari mereka menggunakan Bahasa Indonesia. Adapun ketika mereka berinteraksi dengan mitra tutur yang tidak mereka hormati tetapi akrab 80\% dari mereka menggunakan Bahasa daerah.

Dalam situasi formal 95\% mahasiswa Flores menggunakan Bahasa Indonesia ketika menyampaikan tindak tutur direktif permintaan kepada mitra tutur yang mereka hormati dan akrab. Semua mahasiswa Flores menggunakan Bahasa Indonesia ketika menghadapi mitra tutur yang mereka hormati tetapi tidak akrab dan yang kurang mereka hormati tetapi akrab yang berasal dari luar daerah. Sedangkan dengan mitra tutur yang mereka tidak hormati tetapi akrab yang berasal dari satu daerah, 95\% dari mereka menggunakan Bahasa daerah.

Bahasa Dayak Ahe yang digunakan oleh sebagian masyarakat Kalimantan Barat tidak memiliki tingkatan bahasa, seperti halnya Bahasa Indonesia dan Melayu. Oleh karenanya, dalam penggunaan tindak tutur direktif permintaan pada ranah 
keluarga, masyarakat, dan pertemanan, mereka menggunakan bahasa daerah yang sama. Akan tetapi hal ini berbeda ketika mereka berada di ranah sekolah, $100 \%$ mereka akan menggunakan bahasa Indonesia, meskipun mitra tutur yang terlibat berasal dari suku yang sama.

Seperti halnya bahasa Jawa, bahasa Madura juga memiliki tingkat tutur (speech level) yang berbeda sebagai penanda kesantunan, abhasa (enggi-bunten) dan ta'abhasa (enja'- iye). Abhasa adalah ragam bahasa Madura halus yang digunakan dalam berinteraksi dan menunjukkan kesantunan terhadap mitra tutur $+\mathrm{P}+\mathrm{S}$ dan $+\mathrm{P}-\mathrm{S}$. Sedangkan yang ke dua, ta'abhasa adalah ragam bahasa Madura kasar yang digunakan untuk berinteraksi dengan sejawat (-P+S) (Fajariyah, 2020). Hasil penelitian ini menunjukkan bahwa dalam menyampaikan ungkapan permintaan, 60\% mahasiswa berbahasa Madura, dalam ranah keluarga, 80\% dalam ranah masyarakat, menggunakan ragam bahasa Madura abhasa. Dalam ranah pertemanan, mereka semua menggunakan ragam ta'abhasa. Sedangkan dalam ranah kampus/sekolah, 80\% dari mereka menggunakan Bahasa Indonesia ketika berinteraksi dengan Dosen/Guru dan teman yang berbeda suku.

\section{PENUTUP}

Berdasarkan analisa data di atas, dapat ditarik kesimpulan bahwa penggunaan tindak tutur direktif mahasiswa multikultural yang belajar di Kota Malang dalam konteks kesantunan memiliki pola yang beragam. Dari empat perangkat peminimalisir FTA yang diadopsi dari Brown \& Levinson dalam ranah keluarga, pertemanan, maupun ranah sekolah dan mitra tutur yang berbeda, didapatkan bahwa dalam menggunakan tindak tutur direktif memiliki pola sebagai berikut. Dalam aspek tindak tutur langsung/ tidak langsung, di tiga ranah berbeda, semua mahasiswa multikultural menggunakan tindak tutur langsung, begitu pula dalam aspek honorifik. Penggunaan aspek pembatas (hedge) lebih banyak digunakan dalam ranah kampus. Sedangkan dalam aspek tingkat tutur, hanya mahasiswa Jawa dan Madura saja yang menggunakannya.

\section{DAFTAR PUSTAKA}

Alfi, K. Z., \& Rosita, F. Y. (2019). Pelanggaran Maksim Kesopanan dalam Kolom Komentar Twitter Joko Widodo. Diglosia: Jurnal Kajian Bahasa, Sastra, Dan Pengajarannya, 2(2), 83-92. https://doi.org/10.30872/diglosia.v2i2.pp73-82

Asmorotedjo, A. (2019). BALI JAWI Menghidupkan Kembali Nilai-Nilai Luhur Manusia Jawa. JOGED: Jurnal Seni Tari, 10(1), 1-15. https://doi.org/10.24821/JOGED.V13I1.2684

Astuti, S. P. (2019). Tuturan Langsung dan Tidak Langsung antara Penjual dan Pembeli di Pasar Tradisional Semarang. Nusa: Jurnal Ilmu Bahasa Dan Sastra, 14(2), 239. https://doi.org/10.14710/nusa.14.2.239-252

Barron, A. (2017). The speech act of 'offers' in Irish English. World Englishes, 36(2), 224-238. https://doi.org/10.1111/weng.12255

Brown, L. (2011). Korean Honorifics and Politeness in Second Language Learning. In Pragmatics \& Beyond New Series (P\&BNS). John Benjamins Publishing Company.

Brown, P., \& Levinson, S. C. (1988). Politeness: Some Universals in Language Usage (Studies in Interactional Sociolinguistics 4). Cambridge University Press. https://doi.org/10.2307/3587263 
Dwi, L., \& Zulaeha, I. (2017). Tindak Tutur Ekspresif Humanis dalam Interaksi Pembelajaran di SMA Negeri 1 Batang: Analisis Wacana Kelas. Seloka: Jurnal Pendidikan Bahasa Dan Sastra Indonesia, 6(2), 111-122.

Fajariyah, L. (2020). The social stratification of the Madurese society and its implications on the usage of Bhasa Madhura. Simulacra, 3(2), 165-178. https://doi.org/10.21107/sml.v3i2.7371

Hadiwijaya, M., \& Yahmun. (2017). Kesantunan Berbahasa Dalam Interaksi Antara Dosen Dan Mahasiswa Multikultural. DIDAKTIKA: Jurnal Pemikiran Pendidikan, 23(2), 142-154. http://journal.umg.ac.id/index.php/didaktika/article/view/18

Kroeger, P. R. (2018). Analyzing meaning: An introduction to semantics and pragmatics. Language Science Press. http://langsci-press.org/catalog/144

Leech, G. (2014). The pragmatics of Politeness. Oxford University Press. https://doi.org/10.4324/9781315857381

Liliweri, A. (2005). Prasangka \& konflik komunikasi lintas budaya masyarakat multikultur. LKiS.

https://www.google.co.id/books/edition/Prasangka_dan_Konflik_Komunika si_Lintas/t61oDwAAQBAJ?hl=en\&gbpv=1

Miles, M. B., \& Huberman, M. (1999). Qualitative Data Analysis an Expanded Sourcebook 2nd Edition. SAGE Publications.

Nagaya, N. (2011). The Lamaholot Language of Eastern Indonesia. Rice University

Soeriadiredja, P. (2013). Marapu: Konstruksi Identitas Budaya Orang Sumba, NTT. Antropologi Indonesia, 34(1), 59-73.

Suryadi, M., Subroto, H. D. E., \& Marmanto, S. S. (2014). The Use of Krama Inggil (Javanese Language) in Family Domain at Semarang and Pekalongan Cities. International Journal of Linguistics, 6(3), 243-256. https://doi.org/10.5296/IJL.V6I3.4553

Wardhaugh, R., \& M. Fuller, J. (2006). An Introduction to Sociolinguistics (Issue 1). Wiley Blackwell.

Yule, G. (1996). Pragmatics. Oxford University Press.

Yulianti, A. I. (2017). Campur Kode Bahasa Dayak Ngaju dan Bahasa Indonesia pada Kicauan Twitter Remaja di Palangkaraya. Kandai, 11(1), 15-28. https://doi.org/10.26499/JK.V11I1.213 